\title{
The political logic of dispute settlement: Introduction to the special issue
}

\author{
Christina L. Davis
}

Published online: 2 April 2015

(C) Springer Science+Business Media New York 2015

In the absence of centralized enforcement authority, international institutions have devised a wide range of measures to enforce agreements. At one extreme, states have delegated authority to third party legal bodies to interpret and rule on compliance with authorization of sanctions to punish violations. At the other end of the spectrum, states rely upon peer pressure to encourage compliance and agree to negotiate over any differences of interpretation. Researchers have broadly explored two dimensions of dispute settlement: the variation in design of dispute settlement provisions within institutions and the pattern of state behavior within established dispute processes. This special issue pushes forward research on both dimensions while raising new agenda for probing the political determinants of institutional design and state behavior in dispute settlement. Are judges immune from the influence of power considerations in their rulings? Why do we observe electoral cycles in the pattern of case filings in the WTO? How does sensitivity to interest group pressure shape the structure of dispute settlement? In addition, the articles bring new insights from comparison across issue areas. What explains the variation of dispute design across issue areas? Does legalization of one issue area generate ripple effects that shape behavior for other issue areas? Finally, the articles hone in on critical micro-level differences within dispute settlement. Stepping beyond the issue of why states establish enforcement measures and description of the initiation and disposition of cases, the articles consider details such as the economic stakes at hand and conditions that favor resolving disputes with direct compensation.

The challenge to cooperation arises from uncertainty over compliance given incentives for others to cheat or free ride in the face of mixed incentives and collective action problems. This places dispute settlement at the heart of any theory of cooperation. Institutions work to the extent they can provide information that lowers

C. L. Davis $(\bowtie)$

Woodrow Wilson School and Department of Politics, Princeton University, Princeton, NJ USA

e-mail: cldavis@princeton.edu 
transaction costs for actors to make and enforce their commitments (Williamson 1985; North 1990; Ostrom et al. 1992). The literature on international institutions posits that the lack of liability rules and asymmetric information contribute to market failures at the international level - states that would otherwise benefit from cooperative bargains cannot reach agreement because of the difficulty to credibly commit to comply or allocate responsibility in the case of disagreements and cheating. Keohane (1984) developed a functional theory to show the role of institutions to reduce transaction costs by providing information and mechanisms that raise the costs of non-compliance. Yet just as the transaction cost economics literature searched for institutions that provided alternatives to centralized legal enforcement, much of the study of international institutions began with an emphasis on ways that institutions encourage compliance through such mechanisms as diffuse reciprocity and reputation. These theories focus more on the role of institutions to avoid disputes than on the role of institutions to solve those disputes that occur.

Yet few if any institutions achieve complete compliance. Misunderstandings, differences of interpretation, and willful violations lead to disputes over the behavior of countries that have signed agreements. This gives rise to the need to settle disputes. The stability of institutions depends on mechanisms short of ending all cooperation that allow states to manage these disputes. Many theories focus directly on the role of dispute settlement to sustain cooperation (Milgrom et al. 1990; Rosendorff 2005). The comparison of different forms of dispute settlement examines the variation of legalization and access to dispute processes (Abbott et al. 2000; Keohane et al. 2000; Koremenos 2007). Finally, many studies assess the effectiveness of different dispute settlement mechanisms to resolve the underlying disagreement (Busch and Reinhardt 2002; Bown 2004; Kono 2007; Huth et al. 2011; Davis 2012).

While individual studies address questions about specific aspects in the design and utilization of dispute settlement processes, it is necessary to recognize that dispute settlement serves multiple functions across the different stages of international cooperation. The primary purpose is to resolve a problem so that cooperation can resume, but the dispute settlement process can also sustain future cooperation by deterring violations, closing gaps in treaty interpretation, and helping states to accommodate new circumstances arising from changes in political interests or external conditions. The expected success of enforcement in turn connects to the bargaining dynamic that establishes rules for cooperation (Fearon 1998). The interplay of political incentives and institutional constraints operate at each level of cooperation as states strive to resolve their disputes.

\section{Political underpinnings of dispute design and practice}

Domestic political pressures are often identified as the source of noncompliance (Rickard 2010; Rosendorff 2015). Political pressures also mobilize enforcement constituencies across a range of agreements from human rights to trade policy (Shaffer 2003; Simmons 2009). Davis (2012) develops a theory of how domestic institutions shape the demand for legalized forms of dispute settlement, and presents evidence in the context of the WTO showing that executives use legal complaints as a tool 
for balancing national interest and narrow interest group pressures. In these cases, domestic politics underlies the enforcement of treaties through the use of litigation at home and in international venues. The studies in the special issue highlight new aspects of how domestic political interests shape dispute settlement.

First, at the level of design, states consider the type of pressures they will face in order to tie their hands with the right form of constraints. Pelc and Urpelainen (2015) demonstrate that differences in the mobilization of actors lobbying for defection from trade agreements and investment agreements explain the opposite approach to using compensation as form of compliance. The nature of investment violations opens possibility for efficient breach arguments because governments are the direct beneficiary of the violation and can choose to make payment in lieu of compliance. In contrast, violations of the trade regime benefit industries that would only lobby more for such actions if governments could buy off the need to comply. Therefore governments have vocally rejected the option of efficient breach in the area of trade where they recognize that agreements would unravel under domestic pressures to use the option beyond necessity. But they turn frequently to this same measure to settle disputes over investment violations. The difference of design is even apparent within a single agreement as NAFTA favors compensation for investment disputes and rejects it for trade disputes. This research demonstrates how dispute design reflects who is mobilized and will be restrained by the dispute rules.

Second, at the level of behavior, the pattern of using dispute measures follows a political logic. In both trade disputes and territorial disputes, democracies have been consistently more likely to bring disputes before international adjudication (Allee and Huth 2006; Davis 2012). Pervez (2015) highlights the political utility of filing a WTO dispute for leaders who face an election and demonstrates that governments are more likely to challenge protectionist measures against their exports during the years prior to an election. Such electoral cycles in dispute initiation may also arise in other settings.

Finally, not only the states that use the dispute bodies but also the judges that act within them are sensitive to political pressures. Brutger and Morse (2015) explain how career incentives for appointment lead judges in WTO disputes to show deference to the most powerful states. U.S. and EU losses are significantly more likely to bring the exercise of judicial economy where judges refrain from ruling on legal claims made by the plaintiff.

\section{A Critical look at the role of legalization}

Studies of international law often assume normative idealism and/or functional efficiency. Whether from a belief that states feel a compliance pull from the normative stature of international law or on the basis of institutional theories that portray law as a device to clarify and raise the costs of punishment, most research suggests that international law has a positive effect on cooperation. But at what cost? Excess litigation is condemned by some as the outcome of legalization (Alter 2003; Goldstein and Martin 2000; Simmons 2014). Others criticize the inequity of dispute systems that may be underutilized by developing countries or designed in ways that exploit power 
differentials (Busch and Reinhardt 2003; Bown 2009; Allee and Peinhardt 2014). The special issue presents several other dimensions on which legalized dispute settlement may fail to deliver fully on its potential.

Using courts is costly. In the context of the WTO, obstacles to filing potential cases include inexperience, legal fees, fear of economic or diplomatic retaliation, and the opportunity cost of waiting for a lengthy legal process to reach its resolution (Bown 2004; Davis and Shirato 2007; Davis and Bermeo 2009; Davis 2012). The presumption has been that economic interests are a primary motivation for decisions to file cases. But little evidence has existed to support this view. With a new dataset on product level trade flows for a large set of WTO cases, Bown and Reynolds (2015) show that WTO cases address an average of $\$ 55$ billion dollars of lost trade value from contested trade barriers in any given year. They also document considerable variation in the economic stakes of the issues with some addressing a single product and trivial amount of trade while others have expansive scope in product coverage and or affected trade volume. Economic interests will explain the cases with large trade stakes, while in other cases demand for dispute settlement may sometimes reflect domestic political pressures or strategic litigation aimed to establish precedent for future cases (Davis 2012; Pelc 2014). Athough we still lack a complete theory of case selection, we now have better evidence to document the economic losses that motivate many if not all of the cases. Similar research is necessary to assess the contribution of dispute settlement in other issue areas.

The decision to use third party dispute settlement implies loss of control. Biased judgments are the shortcoming of politicized courts. But for any court there is risk for participants that the ruling will not meet their expectations. Johns (2015) contends that uncertainty about how a court will rule can make states less likely to reach pretrial settlements that would advance their interests, and controversial rulings may lead a state to exit the regime. In a case study of the 1966 ruling of the International Court of Justice in the South West Africa case, Johns shows how a surprise ruling could both undermine the regime and destabilize relations in the region. The efficiency of dispute settlement as a means for actors to complete an incomplete contract by clarifying interpretation or filling gaps depends on the accuracy of the court (Maggi and Staiger 2011). These theories highlight the importance of assessing whether courts play the role of objective arbiter of the law.

Brutger and Morse (2015) address the question of biased judgements in the context of WTO panel rulings. Their evidence shows that panelists are more likely to exercise judicial economy and avoid ruling on issues that pertain to losing claims by the United States or EU as the most powerful actors within the trade regime. They attribute these actions to the career interests of panelists who seek to please the most frequent users of the system. This evidence contributes to ongoing debates over whether courts are constrained by powerful state interests or act as trustees to advance the cause of integration and faithfully interpret the law (e.g. Voeten (2007), Carrubba et al. (2008), Stone Sweet and Brunnell (2012), and Alter (2014)).

Another form of biased ruling occurs when judicial bodies assume a legislative role interpreting agreements. The WTO has also faced charges of judicial activism in the interpretation of trade and environment provisions. Some claim that the protrade orientation of the trade regime leads to biased rulings against environmental 
protection measures. Johnson (2015) offers a nuanced discussion about the role of the trade regime to shape environmental policy. Her article contends that trade law became structurally superior to environmental law when states increased the legalization of the trade regime and granted the WTO authority to rule in environment-related trade disputes. By virtue of the authority and legitimacy of the legal process that stands in stark contrast to the informal mechanisms to enforce environmental agreements, critical policies related to environmental protection have been adjudicated by trade panels. States clearly delineated terms in WTO agreements to allow flexibility for regulations aimed to achieve environmental protection and enforcement of the trade rules so long as a state can provide information affirming why and how the regulation serves environmental protection goals. Johnson highlights the deference provided by panelists to these terms in the agreement as repeated judgments express support for environmental safeguards. Nonetheless, she also notes that trade experts may not be in the best position to make decisions on environmental policies. The procedural strength of WTO dispute settlement design has led the WTO to become the main venue to adjudicate when trade liberalization and environmental protection conflict. ${ }^{1}$

Fear of unpredictable rulings and reluctance to face the costs of litigation can deter states from designing institutions with legalized dispute settlement or choosing to use adjudication measures for a given case. In an even more dramatic retreat from legalization, Ásgeirsdóttir and Steinwand (2015) argue that states may seek to untie their hands from legalized dispute settlement. In the case of the Law of the Sea, states faced the prospect of having maritime boundary agreements brought forward before the International Court of Justice, the International Tribunal for the Law of the Sea, or settled according to UNCLOS arbitration. In a comprehensive analysis of maritime boundary agreements, Ásgeirsdóttir and Steinwand show that a large number of states explicitly specify bilateral negotiations as the means of dispute settlement. They argue that such "Agree to Negotiate" options represent a brake to halt the automatic movement towards legalized dispute settlement. The fact that low income states are the most likely to opt for this strategy suggests that legalized dispute settlement does not equally serve all states.

\section{Toward comparative study of dispute settlement}

Theories about the design of dispute settlement stand to gain leverage from comparison across different issue areas. The rational design agenda sets forth hypotheses about how the nature of the cooperation problem in any given issue area determines the form of enforcement measures (Koremenos et al. 2001). This calls for comparative research on institutional design across issue areas, but much of the literature on dispute settlement continues to focus on one area in any individual study.

\footnotetext{
${ }^{1}$ Marcoux and Urpelainen (2013) argue that environmental agreements contain weak enforcement provisions because otherwise developing countries would refuse to join them.
} 
The longstanding distinction between the trade and investment regimes in their treatment of efficient breach offers comparative opportunity for Pelc and Urpelainen (2015). They demonstrate that variation in the nature of incentives of domestic actors accounts for the two different approaches to dispute design. This contributes to growing number of studies that examine overlapping areas of economic governance for trade and investment (Büthe and Milner 2008; Simmons 2014). Through looking across issue areas, researchers can more carefully identify how political incentives shape both design and outcomes of dispute settlement.

In the search for comparisons, it will be important to cast the net widely. The presence of multiple datasets on WTO dispute settlement and FDI arbitration may bias researchers towards further research on patterns within these issue areas. Ásgeirsdóttir and Steinwand in their study of maritime boundary disputes highlight the potential for new datasets that examine entirely different issues for dispute settlement.

Further it is important for scholars to consider the overlapping jurisdiction of regimes. Johnson (2015) shows how differences in design of dispute settlement can determine which venue will expand its jurisdiction to encompass a variety of issues. In some cases, weak enforcement capacity in one area may lead states to utilize more rigorous procedures available in another institutional setting. Hafner-Burton (2005) shows that preferential trade agreements have at times been more effective than human rights agreements to enforce protection of basic human rights principles. But where these examples imply that a weak regime could borrow enforcement power from another dispute settlement system, overlapping jurisdiction can also fragment the legal coherence of both regimes.

Theories of dispute settlement will also benefit from insights across the subfields of political science, economics, and law. Brutger and Morse extend on the rich tradition in American Politics investigating how personal preferences and the selection of justices shape their decisions. Pervez (2015) adds to the research on electoral cycles in economic policy-making with his finding that election timing shapes the filing of WTO complaints. Bown and Reynolds (2015) connect their product level analysis to economic theories about terms-of-trade incentives for protection. Such efforts to bring evidence to theory advance our overall understanding of dispute settlement.

\section{Articles in the special issue}

Ásgeirsdóttir and Steinwand (2015) present a theory of states backing away from legalization in their choice of dispute settlement. The costs of legalized settlement and demands for flexibility in future conflicts lead some states to prefer bilateral negotiations. Rather than assuming that states seek to bind their hands, research must examine variation in the design of dispute settlement. Koremenos (2007) finds that in comparison across a large sample of international agreements, only half include dispute settlement agreements. In Ásgeirsdóttir and Steinwand's article we find another option for the design of dispute settlement - the Agreement to Negotiate Option (ANO) - that calls on states to defer their option to use legalized venues and commit to first negotiate over how to resolve disagreements. 
They explore which states are most likely to adopt ANO as the form of conflict resolution mechanism in a comprehensive empirical analysis of a new dataset on maritime boundary agreements. Within the multilateral Law of the Sea (LOS) regime that sets guidelines for how states share the resources of the seas, states are left to negotiate the terms of how to resolve overlapping boundaries through bilateral agreements. The Law of the Sea establishes a legalized set of options for states to resolve differences over such agreements by sending disputes to International Tribunal for the Law of the Sea, the International Court of Justice, or through arbitral tribunals. Against this regime context, agreements that do not specify dispute settlement process in the bilateral agreement will default to the legalized LOS options. While the majority of agreements defer to the LOS options by not making any reference to dispute settlement mechanism, 56 of the 186 bilateral agreements in the Ásgeirsdóttirr and Steinwand dataset instead specify bilateral negotiations in an ANO. Their evidence that poor states are the most likely to retreat from legal arbitration through a bilateral agreement to negotiate holds wider implications for the future of international relations. The increasing trend of legalization in a range of institutional venues may encounter backlash by the poorest members of the system that are most sensitive to the costs of using international law. Further, their finding that economic asymmetry also increases the probability of ANO implies that law may be unable to level the playing field if states most in need of such leveling are unable or unwilling to seek it out.

Bown and Reynolds (2015) present a new dataset to explore the product level characteristics of the cases brought before the WTO for dispute settlement. At the aggregate sectoral level, Bechtel and Sattler (2015) have demonstrated that exporters gain by bringing forward cases to the WTO. By focusing on trade stakes involved in disputes at the product level, Bown and Reynolds can highlight several important patterns. Showing that complainants experience more trade loss in the product and are the low-priced exporter with highest market share relative to non-complainants who also export to the target market substantiates the economic interests that motivate enforcement action. Further they highlight that disputes vary widely in their economic stakes and product scope with 14 percent of disputes addressing trade worth less than $\$ 1$ million per year and 20 percent of disputes focused on a single product while others address trade over $\$ 1$ billion per year and/or regulate trade across fifty or more products. Their article raises a new dimension for analyzing protection by whether it is partial or global in scope. Their dataset on WTO disputes at the level of disaggregated product trade builds on research into the economic interests that shape and are determined by dispute settlement.

Brutger and Morse (2015) explore the behavior of WTO panelists for evidence of strategic bias favoring powerful states. They develop a theory grounded in the interests of individual panelists to preserve their own job prospects for future appointment to panels and to support the strength of the trade rules by reducing the likelihood of noncompliance with rulings. Career incentives and systemic stability both induce panelists to show deference toward the major powers.

Brutger and Morse test their theory on data of WTO dispute settlement panel rulings and the use of judicial economy, a practice in which panelists decide not to rule on part of a complaint. They point to evidence that panelists are more likely to 
exercise judicial economy in rulings that go against the US or EU to support their theory of strategic bias. In critical cases such as those against U.S. anti-dumping laws, they show how controversial legal points are dodged through use of judicial economy. At the same time, the politicized ruling process occurs in rulings against the United States and EU - bias induces judicial economy rather than favorable rulings. Judges exercise their discretion in an attempt to reduce the US and EU opposition to these negative rulings. Busch and Pelc (2010) showed judicial economy as a tactic to respond to the opinion from broader membership as indicated by the correlation between third party participation in the proceedings and the exercise of judicial economy. Brutger and Morse offer counterpoint that the opinion of the US and EU may weigh especially large on the minds of WTO panelists.

Johnson (2015) examines the role of dispute settlement for trade and environmental policies. She argues that the trade regime has structural supremacy over these conflicts by virtue of its highly legalized dispute settlement mechanism. The disparate rules on environmental policy lack a rigorous enforcement mechanism and instead defer to the trade regime for adjudication of conflict between the trade and environmental regimes. Yet trade panel judges have been careful to respect rules allowing for restriction of trade when necessary in pursuit of environmental protection. Johnson shows that it is difficult for governments to get away with green protectionism because measures require information revelation about their environmental justification for trade-restricting policies. The cases adjudicated on sanitary and phytosanitary measures illustrate the dominance of trade panelists to issue authoritative decisions based on their own assessment of the conflict of rules, and also the constraints on their ability to dictate against environmental protection goals.

Pelc and Urpelainen (2015) compare the use of efficient breach as means to resolve disputes in the investment and trade policy areas. The ability to pay compensation for a violation can be optimal under some circumstances, but the rules differ sharply in the two regimes with the trade regime disallowing the practice that is quite commonly used in the investment regime. Pelc and Urpelainen theorize that governments reject efficient breach in the case of trade where domestic interest groups would only intensify their lobbying for violations and nullify the value of the trade agreement. The difference for investment policies lies in the beneficiary of violations and their mobilization capacity - to the extent the government itself directly captures the gains from violating the agreement it can internalize the costs of payment without any distortion of incentives. In their argument, domestic politics shapes the variation in when governments want to tie their hands or allow for flexible solutions such as efficient breach.

Pervez (2015) also shows how domestic politics shape dispute settlement in his study about the electoral timing of WTO dispute complaints. Whereas (Chaudoin 2014) examines sensitivity of WTO dispute timing to defendant elections with a study of cases filed against the United States, Pervez considers the political incentives in the complainant state that initiates action and broadens the scope beyond the United States. Surprisingly, governments are not always in a hurry to file a complaint as soon as the trade policy goes into effect against their exports and instead wait for the right political moment to file the complaint. Pervez documents that the approach 
of an election significantly increases the likelihood for a country to challenge antidumping measures. Remarkably it is developing countries that are the most likely to exhibit political timing of disputes. From their position of relative weakness and infrequent use of the dispute system, developing countries maximize on the gains received in terms of both political and market benefits. ${ }^{2}$

\section{Conclusions}

Enforcement measures lie at the center of international cooperation, but range widely in their form and effectiveness. This special issue contributes to the growing attention to dispute settlement design and behavioral studies about the process of using dispute settlement. A better understanding about how states choose to resolve their disputes offers insights into the source of the violations that give rise to disputes.

Rather than fit within one theoretical framework or topic, the papers highlight a wide range of new directions for research on dispute settlement. Several emphasize the importance of political pressures that shape both design and use of dispute settlement. Delegation to a third party channels the response to such political pressures within accepted parameters of action. Nevertheless, evidence of electoral cycles in the filing of complaints and unusual deference by judges toward powerful players and special exemptions illustrate how law can be sensitive to the political contingencies of states.

As research on dispute settlement moves forward, more micro-level data is necessary to test theories about how dispute settlement operates. The special issue introduces two new datasets with the (Ásgeirsdóttir and Steinwand 2015) maritime boundary agreements dispute data and the (Bown and Reynolds 2015) product level WTO dispute data. These offer a valuable resource for future research on disputes, and exemplify best practices for empirical research on dispute settlement. First, in considering dispute settlement design, the question of why states tie their hands through delegation to a legal dispute mechanism requires careful attention to the alternative options such as negotiations. Second, the benefits from bringing forward disputes must be compared to the stakes for the potential complainants that chose not to file a complaint. Both of these points emphasize how careful research design can address issues of selection bias that would otherwise threaten validity of inferences.

Effective dispute settlement mechanisms prevent the recurrence of disputes and uphold the stability of compliance with international commitments. But dispute settlement mechanisms can also consume resources needlessly and aggravate relations between states if the mechanism proves to be too blunt an instrument to solve complex and sensitive problems. States must balance the goal of strong enforcement for the sake of deterrence with the demand for flexibility necessary to accommodate political exigencies. They do so at each stage in dispute settlement when they design the rules and in their choice to exercise the dispute mechanisms.

\footnotetext{
${ }^{2}$ See Guzman and Simmons (2005) for argument that developing countries target larger markets in their complaints.
} 


\section{References}

Abbott, K.W., Keohane, R., Moravcsik, A., Slaughter, A.-M., \& Snidal, D. (2000). The concept of legalization. International Organization, 54, 401-419.

Allee, T., \& Peinhardt, C. (2014). Evaluating three explanations for the design of bilateral investment treaties, 66, 47-87.

Allee, T., \& Huth, P. (2006). Legitimizing dispute settlement: International legal rulings as domestic political cover. American Political Science Review, 100, 219-234.

Alter, K. (2003). Resolving or exacerbating disputes? The WTO's new dispute resolution system. International Affairs, 79, 783-800.

Alter, K. (2014). The new terrain of international law: Courts, politics, rights. Princeton, NJ: Princeton University Press.

Ásgeirsdóttir, Á., \& Steinwand, M. (2015). Conflict resolution mechanisms and maritime boundary settlements. Review of International Organizations, 10, 2.

Bechtel, M.M., \& Sattler, T. (2015). What is litigation in the world trade organization worth?. International Organization Forthcoming, 1-29.

Bown, C. (2004). On the Economic Success of GATT/WTO Dispute Settlement. The Review of Economics and Statistics, 86, 811-823.

Bown, C. (2009). Self-enforcing trade: Developing countries and WTO dispute settlement. Washington, D.C.: Brookings.

Bown, C., \& Reynolds, K.M. (2015). Trade flows and trade disputes. Review of International Organizations, $10,2$.

Brutger, R., \& Morse, J. (2015). Balancing law and politics: Judicial incentives in WTO dispute settlement, Review of International Organizations, 10, 2.

Busch, M., \& Reinhardt, E. (2002). Testing international trade law: Empirical studies of GATT/WTO dispute settlement. In D. Kennedy, \& J. Southwick (Eds.) The Political Economy of International Trade Law: Essays in Honor of Robert E. Hudec (pp. 457-481). Cambridge: Cambridge University Press.

Busch, M., \& Reinhardt, E. (2003). Developing countries and GATT/WTO dispute settlement. Journal of World Trade, 37.

Busch, M., \& Pelc, K. (2010). The politics of judicial economy at the World Trade Organization. International Organization, 64, 257-279.

Büthe, T., \& Milner, H. (2008). The politics of foreign direct investment into developing countries: Increasing FDI through international trade agreements?. American Journal of Political Science, 52, $741-762$.

Carrubba, C.J., Gabel, M., \& Hankla, C. (2008). Judicial behavior under political constraints: Evidence from the european court of justice. American Political Science Review, 102, 435-452.

Chaudoin, S. (2014). Audience features and the strategic timing of trade disputes. International Organization.

Davis, C.L. (2012). Why adjudicate? Enforcing trade rules in the WTO. Princeton, NJ: Princeton University Press.

Davis, C.L., \& Bermeo, S.B. (2009). Who files? Developing country participation in WTO adjudication. Journal of Politics, 71, 1033-1049.

Davis, C.L., \& Shirato, Y. (2007). Firms, governments, and WTO adjudication: Japan's selection of WTO disputes. World Politics, 59, 274-313.

Fearon, J. (1998). Bargaining, enforcement, and international cooperation. International Organization, 52, 269-306.

Goldstein, J., \& Martin, L.L. (2000). Legalization, trade liberalization, and domestic politics: A cautionary note. International Organization, 54, 603-632.

Guzman, A., \& Simmons, B. (2005). Power plays and capacity constraints: The selection of defendants in WTO disputes. Journal of Legal Studies, 34, 557-598.

Hafner-Burton, E.M. (2005). Trading human rights: How preferential trade agreements influence government repression. International Organization, 59, 593-629.

Huth, P., Croco, S., \& Benjamin Appel. (2011). Does international law promote the peaceful settlement of international disputes? Evidence from the study of territorial conflicts since 1945. American Political Science Review, 105, 415-436. 
Johns, L. (2015). Strengthening international courts: The hidden costs of legalization. Ann Arbor: University of Michigan Press.

Johnson, T. (2015). Information revelation and structural supremacy: The World Trade Organization incorporation of environmental policy. Review of International Organizations, 10, 2.

Keohane, R. (1984). After hegemony: Cooperation and Discord in the world political economy. Princeton University Press: Princeton.

Keohane, R., Moravcsik, A., \& Slaughter, A.-M. (2000). Legalized dispute resolution: Interstate and transnational. International Organization, 54, 457-488.

Kono, D. (2007). Making anarchy work: International legal institutions and trade cooperation. Journal of Politics, 69, 746-759.

Koremenos, B. (2007). If only half of international agreements have dispute resolution provisions, which half needs explaining?. Journal of Legal Studies, 36, 189-212.

Koremenos, B., Lipson, C., \& Snidal, D. (2001). The rational design of international institutions. International Organization, 55, 761-799.

Maggi, G., \& Staiger, R.W. (2011). The role of dispute settlement procedures in international trade agreements. Quarterly Journal of Economics, 126, 475-515.

Marcoux, C., \& Urpelainen, J. (2013). Non-compliance by design: Moribund hard law in international institutions. The Review of International Organizations, 8, 163-191.

Milgrom, P.R., North, D.C., \& Weingast, B.R. (1990). The role of institutions in the revival of trade: The law merchant, private judges, and the champagne fairs. Economics and Politics, 2, 1-23.

North, D.C. (1990). Institutions, Institutional Change and Economic Performance. Cambridge: Cambridge University Press.

Ostrom, E., Walker, J., \& Gardner, R. (1992). Covenants with and without a sword: Self-governance is possible. American Political Science Review, 86, 404-417.

Pelc, K. (2014). The politics of precedent in international law: A social network application. American Political Science Review, 108, 547-564.

Pelc, K., \& Urpelainen, J. (2015). When do international economic agreements allow countries to pay to breach? Review of International Organizations, 10, 2 .

Pervez, F. (2015). Waiting for elections: The timing of international trade disputes. Review of International Organizations, 10, 2.

Rickard, S. (2010). Democratic differences: Electoral institutions and compliance with GATT/WTO agreements. European Journal of International Relations, 16, 711-729.

Rosendorff, P. (2005). Stability and rigidity: Politics and design of the WTO's dispute settlement procedure. American Political Science Review, 99, 389-400.

Rosendorff, P. (2015). The political economy of international trade. Oxford University Press Chapter Domestic Politics and International Disputes.

Shaffer, G. (2003). Defending interests: Public-private partnerships in WTO litigation. Washington, D.C.: Brookings Institution Press.

Simmons, B. (2009). Mobilizing for human rights: International law in domestic politics. Cambridge: Cambridge University Press.

Simmons, B. (2014). Bargaining over BITs, arbitrating awards: The regime for protection and promotion of international investment. World Politics, 66, 12-46.

Stone Sweet, A., \& Brunnell, T. (2012). The European Court of Justice, state noncompliance, and the politics of override. American Political Science Review, 106, 204-213.

Voeten, E. (2007). The politics of international judicial appointments: Evidence from the European Court of Human Rights. International Organization, 61, 669-701.

Williamson, O. (1985). The economic institutions of capitalism: Firms, markets, relational contracting. New York: Free Press. 